University of Wollongong

Research Online

Faculty of Law, Humanities and the Arts Papers (Archive)

Faculty of Arts, Social Sciences \& Humanities

$1-1-2011$

Biopolitical correspondences: settler nationalism, thanatopolitics, and the perils of hybridity

Michael R. Griffiths

Rice University, michelg@uow.edu.au

Follow this and additional works at: https://ro.uow.edu.au/lhapapers

Part of the Arts and Humanities Commons, and the Law Commons

Research Online is the open access institutional repository for the University of Wollongong. For further information contact the UOW Library: research-pubs@uow.edu.au 


\title{
Biopolitical correspondences: settler nationalism, thanatopolitics, and the perils of hybridity
}

\author{
Abstract \\ 'How does (post)colonial literary culture, so often annexed to nationalist concerns, interface with what \\ Michel Foucalt called biopolitics? Biopolitics can be defined as the regularisation of a population \\ according to the perceived insistence on norms. Indeed, biopolitics is crucially concerned with what is \\ perceptible at the macroscopic level of an entire population - often rendering its operations blind to more \\ singular, small, identitarian, or even communitarian representations and imaginaries. Unlike the diffuse, \\ microscopic, governmental mechanisms of surveillance that identify the need for disciplinary \\ interventions, biopolitics concerns itself with the regularisation of societies on a large scale, notably \\ through demography. As Ann Laura Stoler has put it, Foucault's identification of these two forms of power, \\ 'the disciplining of individual bodies...and the regularization of life processes of aggregate human \\ populations' has led to much productive work in the postcolonialist critique of 'the discursive \\ management of the sexual practices of the colonized', and the resultant 'colonial order of things'

\section{Keywords} \\ era2015 \\ Disciplines \\ Arts and Humanities | Law

\section{Publication Details} \\ Griffiths, M. R. (2011). Biopolitical correspondences: settler nationalism, thanatopolitics, and the perils of \\ hybridity. Australian Literary Studies, 26 (2), 20-42.
}




\section{Biopolitical Correspondences: Settler Nationalism, Thanatopolitics, and the Perils of Hybridity}

Michael R. Griffiths

$\mathrm{H}$ ow does (post)colonial literary culture, so often annexed to nationalist concerns, interface with what Michel Foucault called biopolitics? Biopolitics can be defined as the regularisation of a population according to the perceived insistence on norms. Indeed, biopolitics is crucially concerned with what is perceptible at the macroscopic level of an entire population - often rendering its operations blind to more singular, small, identitarian, or even communitarian representations and imaginaries. Unlike the diffuse, microscopic, governmental mechanisms of surveillance that identify the need for disciplinary interventions, biopolitics concerns itself with the regularisation of societies on a large scale, notably through demography. As Ann Laura Stoler has put it, Foucault's identification of these two forms of power, 'the disciplining of individual bodies ... and the regularization of the life processes of aggregate human populations' has led to much productive work in the postcolonialist critique of 'the discursive management of the sexual practices of the colonized', and the resultant 'colonial order of things' (4).

Is it too much to say (as Foucault did not, at least not in so many words) that postcolonial texts - these small and particular representations - can be read as expressions or critiques of biopolitical processes? Certainly one can find representations of disciplinary power across the canon of oft-taught postcolonial texts, from Ngugi Wa Thiong'o's critique of colonial policing in Petals of Blood, to Tsitsi Dangarembga's meditation on the affective violence of mimicry in Nervous Conditions, to Salman Rushdie's magical realist parody of Indira Gandhi's state of emergency in Midnigbt's Children. What of the settler colony? As Patrick Wolfe argues, while extraction colonies cannot do without intervention into a colonised population that forms the basis of a labour force, 'settler colonies were (are) premised on the elimination of native societies' (2). And as Chadwick Allen suggests, 'Aboriginal inhabitants of what are now First World nations have been forced to compete for indigenous status with European settlers and their descendants eager to construct new identities that separate them from European antecedents' (9). In the Australian context, the processes of absorption and assimilation directed toward Aboriginal people in the twentieth century clearly involve disciplinary practices driven by the twentieth century clearly involve disciplinary practices driven by often contradictory, claims about a hybrid national future in Australia, in often contradictory, claims about a hybrid national fural inflections of the miscegenation entailed in assimilationist biopolitics. While popular and miscegenation entailed in assimilationist biopolitics. While popular and literary visions of the nation did not always follow the same line of the settler as state biopolitical programs, they stil crafted their visions of the setter nation's future form by interfacing with the projections that emanated from the field of administrative knowledge concerned with the management of population as a biopolitical object.

The normalisation of population was central to the twentieth-century Australian national vision. In the early years of the twentieth century, what came to be known as the 'Aborigines problem' concerned the recognition of a carticularly in the remote a rising population of people of mixed descent, particularly in the remote areas of northern Australia. In 1896, reflecting on his observations as part f the Horn Scientific Expedition, the biologist and influential contributor of the Horn Scientific Expedition, the Australian ethnography Walter Baldwin Spencer wrote that '[i]n contact with the white man the aborigine is doomed to disappear' (cited in McGregor 61). Seventeen years later, however, in his Preliminary Report on the Aboriginals of the Northern Territory, Spencer would be one of the first to note the countervailing tendency in the demography of Aboriginality: to note the countervailing tendency in the number of so-called 'half-caste', 'quadroon', and 'octoroon' Aborigines. 'The question of half-castes', he wrote, 'is a somewhat difficult one to deal with ... it is sincerely to be hoped that as the country becomes more populated, the proportionate number will become less' (Spencer 21) After increased investigation into the question of Aboriginal population, particularly in remote areas of the Commonwealth like the Northern Territory, with its small and precarious white population, it became clear by the 1920s that the number of people of Aboriginal descent was in fact increasing, a fact that confounded the assumption that Aboriginal people were a 'doomed' race.

Russell McGregor has traced the extent to which the doomed race theory remained persistent even as it was gradually displaced in relation to evidence of a rising 'half-caste' 
I want to mark three dates from the late 1930s that index three acutely biopolitical instances of the settler nationalist imaginary:

January 1936. After its first two instalments had been published in The Australian Mercury, P.R. Stephensen's The Foundations of Culture in Australia: An Essay Toward National Self Respect is published in book form by W.J. Miles. A short way into the essay's third instalment, Stephensen would declare, '[a]ll parties agree that population is Australia's paramount need' (149). For Stephensen, a large population was one of the preconditions of a culturally nationalist Australia, independent of the British metropole. Yet, questions of race, hybridity, and the legitimacy of settler belonging would also not be absent from his prose. Coinciding with key transformations in Australian Aboriginal policy, Stephensen's tract would influence a number of nativist and nationalist writers who desired both cultural independence and the incorporation of Aboriginal motifs into their writing; these included Rex Ingamells, Ian Mudie, and, most notably, Xavier Herbert, who would engage with the question of population in his masterpiece Capricornia.

June 1936. Herbert writes to his friend Arthur Dibley, a manuscript reader at P.R. Stephensen and Co., from the verandah of his house in the Kahlin Aboriginal Compound in Darwin (Munro 137). In early 1934, Herbert and Stephensen had worked closely on the revision of Capricornia (Munro 138; De Groen 88-95); indeed, in the early 1960s Stephensen even claimed his role in editing to be so extensive as to warrant co-authorship (Stephensen, 'How I Edited Capricornia'). When he wrote to Dibley, Herbert was employed as acting superintendent of the compound - an agent of the surveillance and discipline of Aboriginal people. In his letter, he wondered as to the likelihood of Stephensen's successful publication of the novel, and clearly related his literary ambitions to grandiose dreams of nationalism and race-consciousness:

Do you know what I've been dreaming of doing? Why, no less than teaching the Aboriginal race to accept citizenship \& win a place in the Nation, \& honourable place [sic], so that they may cross with the

invaders $\xi^{2}$ enrich the new Nation with their blood. Already I have founded

a Euraustralian League, the members of which are Halfcastes and

Quartercastes whose blood is pure Aboriginal and European, the aim of

which is to teach pride of race to these people $\&$ to teach others to honour

them \& ultimately to found a Nation. (Letters 71 , emphasis added).

Herbert's imagined project of a hybrid nation was not only premised on the citizenship of Aboriginal Australians. It was also an appeal to contemporary

population and attitudes toward potential preservation of 'full blood' natives through reserve land (60-99). racial science that envisioned 'enrich[ing] the new Nation with [Aboriginal] blood'.

April 1937. The initial Conference of Commonwealth and State Aboriginal Authorities on Aboriginal Welfare takes place in Canberra, unifying across the Commonwealth what was perhaps the most notoriously racist manifestation of assimilation's biological, eugenicist form: absorption. Bringing together various state protectors, as well as the Chief Protector in the Northern Territory, Cecil Cook, the conference sought to articulate a sovereign decision - in Giorgio Agamben's sense - on the future of the Aboriginal population as a whole, and, implicitly, the norms to which white Australia would be subject. It was here that disciplinary policies of child removal and the regulation of marriage based on blood and colour would coalesce in accordance with the White Australia policy. At the conference, Western Australian Protector A.O. Neville insisted that 'the problem of the native race, including half-castes, should be dealt with on a long-range plan $\ldots$ by accepting the view that ultimately the natives must be absorbed into the white population of Australia' (Commonwealth, 11). Neville had been implementing these techniques of intervention since 1915 and Cook had spoken of 'breeding out colour' since the 1920s; here they would become official policy for all states and territories, policies that would only be interrupted by the outbreak of war (Gray 173-202). One of the cadre of 'Aboriginal experts' present at the conference, J.B. Cleland, had been foundational in constructing the biological epistemology underlying this state avowal of miscegenation. As historian Warwick Anderson's work has shown, Cleland had used the analysis of Aboriginal blood type to claim that the Aboriginal race was an archaic branch of a Caucasian genealogy (209-15). At the 1937 Canberra conference, Cleland declared that

[a] very unfortunate situation would arise if a large half-caste population breeding within themselves eventually arose in any of the Australian states ... there can be only one satisfactory solution to the half-caste problem, and that is the ultimate absorption of these persons into the white population. I think that this will not necessarily lead in any way to deterioration of type, inasmuch as racial intermixtures seem, in most cases, to lead to increased virility. (Commonwealth, 10)

In other words, while the question of a large population of Aboriginal people of mixed descent had come to generate great anxiety for the sovereignty of the colonisers in the earlier part of the twentieth century, miscegenation came to be understood as a means to reverse that demographic trend. The Adelaide School of physical anthropology was able to provide a taxonomy, undergirded by technological and experimental claims about blood type and 
racial distribution, and this cadre of pseudoscientific experts sanctioned the view that intermixture between 'Caucasian' peoples and Aborigines would not risk a 'deterioration of type' through the introduction of atavism into the dominant population (Anderson 191-252). This 'science' saw the birth of absorption as articulated through Neville's call for a 'long range plan' of eugenic transformation.

So the 1930s saw literary nationalists like Stephensen and Herbert develop visions that were deeply enmeshed in questions of population. At the same time, the various state Native Administrations proffered the notion that the homogeneity of the national population could be attained through the absorption of the rising population of people of mixed Aboriginal and European descent. While the positive racism of figures like Herbert cannot be simply equated with the adoption of miscegenation as a tactic for governing Aboriginal people, nonetheless I want to sugges that an understanding of the political history of biopolitics in Australian Aboriginal policy can frame a reading of such canonical works of the period as Capricornia. Only by employing such a reading strategy can we emphasise the racial policies that parallel such apparently benign avowals of a hybridity enriched by Aboriginal 'blood'. The history of literary nationalism in Australia, I contend, corresponds with the biopolitics of Aboriginal 'protection', 'absorption', and 'assimilation'.

Settler colonial biopolitics, moreover, often operates through a process in which the imagined disappearance of indigenous peoples corresponds to a nativism that appropriates colonised forms of their customs and motifs. Robert Dixon has called this appropriative colonising process 'plagiarism' For Dixon, '[c]olonial texts ... are built up by plagiarism, whose Latin root, plagiarius or kidnapper, resonates with the history of indentured labour ... The plagiarism performed by colonial texts is a theft of cultural materials, another form of blackbirding, a kind of captivity' (101). Here I will first trace the way absorption - and, to a lesser degree, its inheritor, cultural assimilation - maintained continuity with the nineteenth-century vision of the disappearance of Aboriginal people. Where this disappearance had once been conceived as evolutionarily inevitable, it came to be imagined as eugenically manufacturable through interventions in the Aboriginal population. I will then turn to trace the reliance of Australian literary nationalism on racial and crypto-Lamarckian ideas of physical adaptation, before returning to a reading of related themes in Herbert's work.

\section{From Sovereign Power to Natal-Thanatopolitics}

Colonial governance often relied on a diffuse oscillation between power over population, disciplinary control of individual bodies, and the retention of the sovereign power to take life or subject it to special conditions exceptional to the rule of law as it theoretically pertains to citizen subjects. ${ }^{2}$ Michel Foucault argued in his 1975-76 lectures at the Collège de France that at a certain point in nineteenth-century European history,

beneath the dramatic and somber absolute power that was the power of sovereignty, and which consisted in the power to take life, we now have the emergence, with this technology of biopower, of this technology of power over population as such, over men insofar as they are living beings. It is continuous, scientific, and it is the power to make live. Sovereignty took life and let live. And now we have the emergence of a power that I would call the power of regularization and it, in contrast, consists in making live and letting die. (Society Must Be Defended 247)

Settler colonialism in Australia does not follow Foucault's chronology in any neat or transplantable way. As such historians as Henry Reynolds and A. Dirk Moses have argued, frontier contact between Aboriginal people and settlers in nineteenth-century Australia led to settler violence of the imperial pacificationist mode, which continued to rely on sovereign power over the life and death of colonised people. Overwhelmingly, the nineteenth century was a period wherein settler Australians exercised an unbridled sovereign power over the territory of the colonies. In this paradigm, Aboriginal people were frequently described in the subhuman reckonings of the day and therefore rendered, in Giorgio Agamben's terms, bomo sacer - able to be killed with impunity (Homo Sacer 71-74). As Yuet Noongar Aboriginal Elder Cuimara Ben Taylor puts it, "ii]n the old days we were regarded as fauna, like the kangaroo. We were forced to live in degrading, dehumanising conditions' (99).

In the late nineteenth century, the social Darwinist discourse of the 'doomed race' had become a key and pervasive narrative of extinction that framed visions of the future fate of Aboriginal people (McGregor 19-59). Demographic surveys were occasional and sporadic in the nineteenth century and, as such, evidence to contradict and complicate the doomed race theory was not forthcoming until the series of expeditions and fact-finding missions which, in some sense, began with the 1896 Horn Expedition and

2 On the discipline of the body, see Foucault, Discipline and Punish (28-31); on biopolitics and the subjection of separated populations, see Foucault, Society Must Be Defended (255-56) and The History of Sexuality (133-60); on sovereign exceptions, see Agamben, Homo Sacer, and State of Exception. 
intensified in the early twentieth century, for example in the Commonwealth Expedition of 1911 (see Watts 26-47 and Rowse, 'Notes' 314-16). One way to understand the continuity between frontier violence and the doomed race theory is to see both as part of a thanatopolitics, a politics of death, in the terms that have been outlined by Giorgio Agamben and Roberto Esposito or, alternatively, as a necropolitics, in Achille Mbembe's terms (Homo Sacer 136-65; Esposito 110-45; Mbembe 11-15). One could even turn back to Foucault and his initial formulation of the connection between race and death within the logic of sovereign power. In his lectures, Foucault asks pointedly how race, death, and sovereignty continue to be bound together even after the modern turn to biopolitics:

What in fact is racism? It is primarily a way of introducing a break into the domain of life that is under power's control: the break between what must live and what must die. The appearance within the biological continuum of the human race of races, the distinction among races, the hierarchy among races, the fact that certain races are described as good and that others, in contrast, are inferior: all this is a way of fragmenting the field of the biological that power controls. It is a way of separating out groups that subsist witbin a population. (Society Must Be Defended 255-66, emphasis added)

Whether through punitive expeditionary killings or through the mere assumption of the inevitability of the death of the Aboriginal 'race', the nineteenth-century entwining of race and death left little place for Aboriginality in the imaginary future of the settler nation. The sanguine acceptance of the belief in the extinction of the Aboriginal 'race' continued into the twentieth century as part of the retention of the logic of sovereignty that depicts as inevitable 'what must live and what must die'. However, as I have argued, in the twentieth century the resilience of Aboriginal people in the face of colonisation soon provoked a panic over the rising mixed-descent Aboriginal population, and challenged the 'doomed race' orthodoxy. The late nineteenth and early twentieth centuries would thus see a shift in the internal policy of the new settler nation. Measures for the biopolitical regulation of the Aboriginal population via forced breeding, the removal of children, and the regulation of marriage, often articulated via the categorisation by blood and relative 'tribalisation', had emerged as colonising tactics couched through the rhetoric of 'native protection'. It is this shift that becomes meaningful in the discourse of cultural nationalism that appeared most forcefully in the 1930s. For Foucault, the vast generality of colonising attitudes, European racism, and biopower generally, perceived 'the death of the other, the death of the bad race, of the inferior race ... [as] something that will make life in general healthier and purer' (Society Must
Be Defended 255). That is to say, the thanatopolitics of race was typically associated with the health of the colonising population.

What happens when the means of colonial elimination breaks with this epistemology of degeneration - as it did under the Australian 'native administration'? As Anderson has shown, the single biggest exception to the form of colonial racism displayed in Australia in this period comes in the rearticulation of degeneration. The physical anthropologists based at the University of Adelaide and the Adelaide Museum would change the terms of racial classification in Australia. Using physiognomic testing and calculations based on blood type, the Adelaide school taxonomically positioned Aboriginal Australians as 'dark' Caucasians rather than members of a polygenically divergent race that posed a threat to the racial norms of settler society (Anderson 225-52). This school included such figures as Frederic Wood Jones, Norman Tindale, and, notably, J.B. Cleland. As Anderson puts it:

Cleland and his younger Adelaide colleagues predicted that dark Caucasian genes would eventually be submerged in the larger white Caucasian gene pool, and then proper training and instruction in hygiene - the same discipline as inculcated in poor whites - would do the rest ... Cleland could thus predict a day when, as the result of a scientific breeding and education program, all Australians claimed some Aboriginal ancestry. (227)

This 'science' functioned to legitimise the policy of absorption as articulated in such utterances as Neville's 1937 call for a 'long range plan' of eugenic transformation. For Neville, 'the problem of the native race' could now be given a chilling final solution, whereby 'ultimately the natives must be absorbed into the white population of Australia' (Commonwealth, 11). The notion of the disappearance of the 'native' returns in the biopolitical moment in the mode of absorption: the death of the 'native' is replaced by 'breeding out' (in Neville and Cook's terms) and disappearance into the white gene pool. Here one can trace a continuity with the thanatopolitics of frontier violence and the notion of the doomed race. The 'native' is now to be destroyed not by being put to death, but by a program of eugenics formed around the strict control of childbirth and rearing. Assimilation, with its disruption of kinship systems, its child removal policies and its regulation of marriage was a natal-thanatopolitics: a politics of death through the discipline of birth.

It is in this discourse of absorption that one can mark the shift from sovereign power, with its absolute right over life and death, to biopower. In his excellent study of the Central Australian ration system, Tim Rowse 
identifies that system not only as a mechanism of economic exploitation but also as one embodying the Foucauldian transition 'from a primarily punitive law [over Aboriginal people] to official efforts to inspire Indigenous conformity to an Australian "norm" (White Flour White Power 8). As Foucault puts it, 'the norm is something that can be applied to both a body one wishes to discipline and a population one wishes to regularize' (Society Must Be Defended 253). Regularisation should be read as the effect of this normalisation on the whole macroscopy of the population seen through a wide lens via technologies of the census and of demography; as historian Gordon Briscoe has argued, demography and health subsequently took on a decisive role in constructing identity (1-45). Similarly, historian of social hygiene and Australian nationalism Allison Bashford argues that while 'the blood lines Foucault was interested in were largely about preserving the pure past', eugenics and its effects in the administration of public health 'problematised the sexual and racial connection between the present generation and its progeny - one, two, one hundred generations into the future' (166). The body of the colonised was to be rendered normative in relation to a process of regularising the population as a whole and this process was directed at the future. What I have called natal-thanatopolitics should be understood as the way this normativising project imagined a future from which Aboriginal people were absent not only as a result of settler violence, nor the Darwinian logic of extinction, but also as the result of the emphasis on birth and marriage regulation inseparable from the discourses of protection, absorption, and assimilation. In a chilling rhetorical question, Neville asked: '[a]re we going to have a population of $1,000,000$ blacks in the Commonwealth, or are we going to merge them into our white community and eventually forget that there ever were any Aborigines in Australia?' (Commonwealth, 10).

It is with the notion of the norm - uniting the application of power and its vision for the whole population - that we can return to make some sense of the strange correspondences between settler nationalism and settler colonial biopolitics indexed by the three events of the late nineteenthirties with which I opened. While cultural nationalists like Stephensen and Herbert did not necessarily embrace the thanatopolitical vision of an Aboriginal race engineered out of existence, they proffered hybrid visions that - like Cleland's vision of absorption - were also keyed to norms and their ability to regulate population. Cultural nationalism would embrace the assimilation of Aboriginality, often as a melancholic appropriation of both Aboriginal culture and Aboriginal 'blood' (Rosaldo 71).

\section{Euraustralian Story: Literature, Nationalism, and Biopolitics}

Just as the absorptionist policy of the 1930s Native Administration foresaw the disappearance of Aboriginality (with a hybrid remnant in the 'ancestry' predicted by Cleland), so too did cultural and literary nationalists in the 1930 s articulate their discourse in relation to the nation's perceived future. This correspondence of nationalism and biopolitical demography cannot be ignored. In reading Australian literature, the embrace of hybridity needs to be situated in regard to government programs advocating miscegenation as a path to absorption. In Australia, hybridity and miscegenation have often functioned in parallel - one an optimistic cultural production of the disciplinary operations of the other. Much of this has to do with the way hybridity and miscegenation are, in their own ways, produced for the benefit of settler subjects, 'eager to construct new identities that separate them from European antecedents', as Allen (9) put it. Where a biopolitics of miscegenation attempts to regulate colonised populations - whether the goal was overtly thanatopolitical or not - it may not be possible to decouple its ends from those of an ostensibly benevolent, apparently unrelated, but in fact correspondent cultural politics of hybridity. As Graham Huggan has recently argued,

The problem is not, as some might see it, how to turn the prohibitionary rhetoric of 'miscegenation' into the permissive possibilities of 'hybridity.'

It is rather that hybridity itself is an inadequate mechanism for

counteracting a white-colonial racial imaginary; indeed hybridity might well be seen as part of the very white-colonial racial imaginary it is often called upon to dissolve. (96)

The apparently critical slippage between miscegenation and hybridity that Huggan identifies indexes what I critique as a biopolitical correspondence. Here, correspondence in the sense of letter writing, unpublished and concealed discursive spaces that draw in the epistolary encounter, suggests the discursive networks that link actors in the colonial administration and those in cultural and literary nationalist circles. Such networks exceed the public reception of authors as purely literary figures, as has been emphasised in the Australian context by Philip Mead. But the idea of correspondence is also a way of evoking the relationship between mechanisms of control over population and the cultural imaginary of an emerging literary nationalism that is a good deal more nuanced than a simple notion of causality might suggest. Ideas of demography animate fantasies of culture, but they do so only in a subterranean manner, connecting the symbolic grammar of raw demographic data with imaginary projections of cultural futurity. Here I emphasise the paradoxically privately networked public sphere of 
letter writing as one such underground correspondence. While experts on the 'Aboriginal question' were imagining the 'long-range plan' by which Aboriginal presence would be evacuated from the national scene, literary nationalists were attempting to position their visions of future homogeneity in relation to the 'Aborigines question'. On either side of the correspondence, a rhetoric of the future of the nation as a whole lay at the centre of debate.

Stephensen had been highly concerned with the question of population. Herbert also commented on northern Australia's sparse settler population in the opening pages of Capricornia, indicating the centrality of the issue to his project. Yet while Herbert noted that 'the non-native population' of his fictional township 'numbered no more than three thousand', he also remarked on the decimated Aboriginal population. In doing so, Herbert may have been layering tragedy and irony, but he nonetheless affirmed the resignation of many commentators of the time: 'the civilising was so complete that the survivors of the original inhabitants numbered seven' (Capricornia 6). The tragic register of Aboriginal death is also a troubling encoding of the thanatopolitical register of the doomed race theory. A whole re-evaluation of the Australian literary public sphere of the midtwentieth century would be necessary to trace the pervasive correspondence of the insistence on the notion of Aboriginal extinction, or its supplanting by this perilous hybrid nationalism, with the biopolitics of absorption and assimilation. In this section I want to offer a necessarily partial sketch of the influence of biopolitical ideas about population, race, and nation as they entered this public sphere

Stephensen's three-part essay The Foundations of Culture in Australia: An Essay Toward National Self Respect precipitated a great deal of dialogue and literary activity not only about Austrilited a great deal of dialogue nationalism generally, but in influence, and the cultural transformation of the settler nation. Stephensen's lay familiarity with the anthropological ideas of the time greatly influenced his framing of the quasi-biological dimension that accompanies the cultural nationalist assertions of his essay. He was interested in the longterm effects of racial admixture and an almost Lamarckian transformation on the future population of Australia. 'Culture in Australia', he wrote, 'if it ever develops indigenously, begins not from the Aborigines, who have been suppressed and exterminated, but from British culture, brought hither by Englishmen, Irishmen, and Scotsmen through the Nineteenth Century' (12). The capacity for settler Australians to identify their own independence would rely on a biological transformation; as the book's opening credo went, '[a] new nation, a new buman type, is being formed in Australia' (11, emphasis added). Stephensen's essay was, in many ways, the catalyst of the Jindyworobak movement. According to his biographer, Craig Munro, Stephensen had some familiarity with developments in physical anthropology and a particular investment in theories about the diffusion of the human species. While he may or may not have known Cleland's ideas about Aboriginal racial type, he was certainly aware of those of Carl Tüber, who had published findings in 1932 claiming that human life originated in Australia. In his Busbrwackers, Stephensen's character Dr Morpeth would become the mouthpiece for some of the resultant views on the place of race in Australia: 'On the Australian plains Man learned to walk upright! Then he crossed to India, the home of the Aryan race ... The Aryan race began in Australia. Australia is the original home of the white man' (cited in Munro 123-24). For Stephensen, not only was colonisation of Australia the white man's destiny but this destiny also tied the culturally independent settler nation to the parallel fate of Aboriginal Australians. This understanding of racial destiny led Stephensen's journal the Publicist to support the policy of absorption despite public outcry against its methodology of miscegenation (Munro 188). Ironically, Stephensen also worked with the Aborigines Progressive Association on organising the protest against the Sesquicentenary Celebrations (see Munro 185). Needless to say, Stephensen's attitude toward the 'Aboriginal question' was complex, particularly when nativism, Australian independence, and the concerns of Aboriginal people coalesced. Though it was cultural nationalism, with its bulwarks of homogeneity and independence, that he most prioritised, he repeatedly insisted on the place of Aboriginal people in his and the Publicist's vision for the nation. And while 'concrete' political action and 'control of the political system of the Commonwealth' would be needed to attain literary and cultural nationalism's immediate goals, The Foundations of Culture in Australia also cited a nationalist 'argument from physical Geography' (141-2): 'physiographic factors work slowly ... Ultimately the Australian race will be quite different from the "English" race and hence Australian literature will be quite different from the merely English literature, of England' (141). The attitudes toward racial descent that Stephensen acquired from his reading of Tüber meant taking seriously Aboriginal blood as well as 'physiographic' change in the settler stock, and each played a role in envisioning the hybridity that could undergird a homogeneous and independent nation. For Stephensen, the milieu of the Australian environment, combined with an argument for the racial 'Aryanism' of both Aboriginals and Anglo-Saxons, would ensure Australian independence from Britain. The cultural contribution of Aboriginal life 
seems, for Stephensen, to have acquired value primarily as a means to a nationalist end: the making of a 'new human type'.

Stephensen's ideas about environmental influence and the production of a new Australian 'human type' were highly influential, particularly for the Jindyworobak movement founded in 1937 by Rex Ingamells. Ingamells was more directly impressed by Aboriginal tradition than Stephensen, naming the group for an Aboriginal word meaning 'to annex, to join' (Conditional Culture 4). He was 'vividly impressed' by Stephensen's essay, but also complained that it was 'not Australian enough' ('Introduction' 10). Despite this, Ingamells appears to have accepted and accentuated Stephensen's notion of 'physiographic factors' in producing a 'new human type' in Australia; Ingamells' term for this physiographic influence on culture was environmental values'. In 1937, while Neville and his colleagues were deciding upon the mode by which Aboriginal people were to be 'absorbed' into the white population of the Commonwealth, Ingamells was publishing his first ideas about the relationship between Aboriginal influence, environmental factors, and the making of an independent Australian literature. This was the source of the metaphor of joining. For Ingamells, the Jindyworobaks are 'the few who seriously realise that an Australian culture depends on the fulfilment and sublimation of certain definite conditions', among which he cited 'a clear recognition of environmental values', and ' $[\mathrm{a}] \mathrm{n}$ understanding of Australia's history and traditions, primaeval, colonial, and modern' (Conditional Culture 4-5).

Ingamells saw 'primaeval' Aboriginal tradition as a cornerstone in the poetic inspiration of a distinctive Australian mode. Yet the Aboriginality he identified was an artifactual he identified was an artifactual construction, with little connection to the continuity and change in (post)colonial Australia. Ithat

[w] hen I see wommeras, spears, bullroarers, boomerangs, dillybags, message sticks, tjurungas and wax figures in the Aboriginal dibags, of our museums, and when I read scientific the Aboriginal sections reminiscences dealing with Aboriginat occulises and pionee ceremonies and so ceremonies and so on; I am strongly conscious, often unhappily so, of much in our colonial tradition. As a people it is our duty to be familiar with these things. In them must spread the roots of our culture. Our culture must make artistic realizations of these things and the spirit permeating and engendered by them acceptable to the world. (17)

Yet the fact that Ingamells had only encountered Aboriginal culture as artifacts in museums indicates the degree to which Aboriginal influence was to be an inheritance of 'spirit' that did not challenge the thanatopolitics of the idea that Australia's indigenous people made up a 'doomed race'. Ingamells confirms this as he writes that '[a]lthough such a culture has itself, for the most part, died with the tribes, something of its spirit has been preserved' (17). This notion of a 'spirit[ual]' appropriation of Aboriginality, with its veiled relation to 'environmental values' as eugenic transformation, was not merely a passing fancy of individual writers like Stephensen and Ingamells. In fact, the notion had a much broader influence, as did the idea that Australian nationalist writing could conjure an organic rootedness in step with the 'scientific treatises' (as Ingamells had it) of the time. T.G.H. Strehlow, himself an ethnographer and social scientist, in a 1948 Jindyworobak retrospective publication, wrote that:

[s]cience has pointed out to us that man has managed to reach every part of the globe and to live in every type of environment mainly by adapting himself to his environment and by making the fullest use of its natural resources. I believe that Australian writers, using the same principle, will in the future come more and more to love their country, its trees, its flowers, its animals, and its physical features. (35)

In her own appreciation, appearing in the same volume, Dymphna Cusack made the explicit connection to the influence that contemporary anthropology had on such literary movements. Jindyworobak, she wrote, was 'an aesthetic application of the discoveries of modern anthropology and psychology' (44). Nationalist men of letters like Stephensen and Ingamells not only crafted the relation between Australian nationalism and indigenous culture through incidental means but also in rapport with their - often partial - understanding of the contemporary 'discoveries' of 'anthropology', 'psychology', and, arguably, native administration.

Where Ingamells unquestioningly retained the idea of the 'passing of the Aborigines', Herbert, as we have seen, avowed a notion of 'Euraustralian' hybridity as the organising frame by which Aboriginal survival could be understood. Similarly, if both Stephensen and Ingamells were less explicit about assimilation, Herbert came closer to avowing its techniques of protection and intervention - if not its vision of Aboriginal disappearance. For his part Herbert also believed himself to be an expert on the anthropology of the time. On 27 April 1936, he wrote to Dibley with a scheme to study the texts of the University of Sydney's course in Anthropology, complete a paper and 'request ... an honorary diploma or some such recognition' (Letters 64-65). Unlike his literary nationalist colleagues, Herbert had actually briefly served as a functionary of the Native Administration in Darwin. In a subsequent letter, Herbert represented his 'ordinary anthropological knowledge', as gained from the 
normal course of acting as Superintendent of Kahlin Compound; Herbert seems to have accepted the contemporary premise that the epistemologies of anthropology and administration were closely linked. He also convinced Sydney anthropologist A.P. Elkin to recommend him as a Patrol Officer in the Administration, though he later turned the position down (Letters 127). Herbert saw in assimilation an opportunity not for the disappearance of the Aboriginal people as a 'race', but rather for a form of transformative hybridity that would strengthen the settler subject. He didn't see the administration and surveillance of Aboriginal people as inimical to his nativist desire to belong to the country as authentically as its indigenous population. In a letter to Stephensen of mid-1936 praising The Foundation of Culture, Herbert confessed that he 'dream[ed] of being made a patrol officer, so that I may go right home to the old people and become one of them' (Letters 70). Herbert's writing sentimentally tied both his nationalism and his settler identity to Aboriginality. Where this vision faltered, as we shall see, he would inscribe the tragic deaths of Aboriginal characters in his novels.

It is difficult to ascertain the degree to which Herbert was aware of the taxonomic claims about racial descent proffered by such figures as Cleland. Herbert's vision of national enrichment through miscegenation clearly embraces the value of Aboriginality in a way that absorptionist rhetoricians like Neville did not. In a 1937 letter from the Kahlin Compound to A.P. Elkin, Herbert had remarked that 'the Euraustralian is a very fine type of young man' (Letters 105). The year before, he had proposed to Stephensen what would eventually become Poor Fellow My Country in the postscript of a long letter praising The Foundations of Culture: 'Someday I shall write 'True Commonwealth', a vast tale of the Euraustralians and the birth of the happiest nation on Earth and some day I shall father a Euraustralian so as to truly root myself in this dear earth and so as to legitimize my bastard whitefella genius' (Letters 71). For Herbert, this imaginary fathering of a 'Euraustralian' was apparently fundamental to the project of settler literary independence and legitimacy. His vision of a future nation is as tied to miscegenation, as was that of the assimilationists he often opposed and criticised. ${ }^{3}$ It would do to track the trajectory of this project from Herbert's

3 Herbert spent some energy attacking individuals in the Administration whom he saw as corrupt, notably NT Chief Protector Cecil Cook; in 1937 he wrote to Elkin denouncing Cook's administration (Letters 88-91). The full letter is held in Elkin's personal papers at the University of Sydney (Herbert to Elkin. Elkin Personal Papers, Box 72). In this longer version of the letter, he writes: '[h] ow could I tell [Cook], whom it was my ambition gradually to wean from his vanity to my way of thinking, that he is regarded by the natives not as their Chief Protector, but as the Chief white Debbil-debbil of the land. Natives run miles to avoid him'. Many administrative figures would enter
Capricornia to Poor Fellow My Country. I will not endeavour to provide exhaustive readings of either text, but rather to emphasise the correspondence of Herbert's literary project to a positive paternalistic racism of hybridity that recalls certain elements of assimilation's biopolitics. Both Capricornia and Poor Fellow My Country can be read as tragedies of colonial contact and cultural clash. While the former recounts the 'Euraustralian's' lack of acceptance by the white community, the latter bemoans the tragic loss of the 'Euraustralian' ideal.

In Capricornia, Herbert would emplot discussions of Aboriginal policy which framed both his views on and his frustrations with the Aboriginal administration of the time. While his novel is known for the remarkably sympathetic tone with which it approached its 'half-caste' protagonist Norman, it would also present a policy vision reminiscent of assimilation. The novel's Peter Differ, father of several children by Aboriginal women, advises Norman's uncle Oscar Shillingsworth to take an assimilationist view on his upbringing. He insists that the 'Binghis are really highly intelligent ... Trouble is the white man won't teach 'em anything that might raise 'em a bit' (Capricornia 70). Shillingsworth objects with thanatopolitical rhetoric'it's not much use worrying about them now. They're dying out' - to which Differ rejoins by reference to a rhetoric of the transformation of the rising population - 'thousands and thousands of them' - through education (71). 'Send 'em [to school]', Differ insists, '[k]eep at it generation after generation. Don't look for immediate results' (71). The rhetoric of 'generations' - of the future of the colonised as a eugenic speculation - reveals that the focus on cultural transformation that defined assimilation is also imbricated in a biopolitical logic of intervention into population (Griffiths).

One key thread of Capricornia's narrative concerns Norman's gradual acceptance of and pride in his Aboriginality. 'This narrative thread comes to fruition in the second key discussion of the book between Andy McRandy and Norman, with Norman's father Mark Shillingsworth, in his persona as Jack Ramble, looking on. Like Differ, McRandy is a combo character - a white man who pursues Aboriginal women sexually - through whom Herbert articulates his vision for Euraustralian hybridity. Indeed, one might consider the degree to which Herbert's characters of wisdom and insight are frequently those who marry Aboriginal women. Herbert does not cover over the degree to which such men were, in reality, often ignoble and sexually exploitative; Mark Shillingsworth himself is a white absentee father. However, I would suggest that Differ and McRandy, as combos

Herbert's fiction as parodic caricatures. Cook, for instance, would become Poor Fellow My Country's villainous Dr Cobbity. 
who marry Aboriginal women, embody Herbert's idealisation of 'bastard whitefella genius' through fathering Euraustralian children.

At this point, Norman, sensitive about the recent revelation that he is not - as his uncle had led him to believe - a Javanese prince, but is, in fact, part-Aboriginal, is questioned by McRandy as to the source of his sensitivity: 'What have you got to be ashamed of 'em about?' (286). McRandy then launches into a long defence of Aboriginal tradition: 'If you know anything about the Binghis in their native state, you can't help but honour 'em, unless you're a fool' (288). This defence culminates in an avowal of the future of the 'new Nation' and of Aboriginality's place in it. McRandy's argument is reminiscent of Cleland's ethos. Where Cleland could predict a hybrid future through 'a scientific breeding and education program', McRandy insists that

the day'll come in your own time when your Old People'll be recognized as our Old People too, as the Fathers of the Nation, and'll be raised to a place of honour. No exaggeration. There's signs of it now. Twenty years ago they was killing off the Binghis around here like Dingoes. The Government didn't mind at all ... The people of Australia are waking up to the fact that they've got a responsibility in Brother Binghi. (288)

Not only does Herbert position Aboriginal tradition as the basis for a future national culture, he also reflects on and avows the transition from frontier violence to the discourse of protection and assimilation: the future of 'Brother Binghi' is a 'responsibility' that registers with the making of a future nation. The telos of assimilation and the vindication of the 'Old People' is to provide a foundation for the new nation. Sean Monahan observes, 'for all McRandy's praise for Aboriginal tradition, there is no suggestion that it has anything to teach white Australia. It is not Norman's Aboriginality that provides hope for the future but his genius for white technology' (65). Herbert's contemporary statements outside the text challenge the reading that his use of McRandy's voice reveals no role for Aboriginality in white Australia; still, Monahan's point remains salient in light of Herbert's emphasis on the effect that Aboriginal 'blood' will have on the settler subject and the new nation. For Herbert, we saw, fathering a child by an Aboriginal mother is a legitimisation of his self-described 'bastard whitefella genius'. This act would transform the cultural cringe of bastardry and illegitimacy into a new hybrid identity independent of Britain. In this way, 'Aboriginal blood' enriches Norman's 'whitefella genius'. Where Cleland envisaged a hybrid utopianism for which living Aboriginality would be merely a memory, Norman learns pride in his Aboriginal ancestry, bolstering the future 'bastard' genius that, as Herbert's letters reveal, is nonetheless the eugenic undergirding of a future nation-state. Norman's apprehension of pride from McRandy is thus vested in a vision of futurity similar to that held by such assimilationists as Cleland. While that future day may involve 'Aboriginal ancestry', and appropriation of the ways of the 'Old People', it also involves the inscription of whiteness. For McRandy (as for Neville and Cleland) 'colour' has no place in the future: 'The black feller ain't a Negroid type. His colour's only skin-deep. Three cross-breedin's and you'll get the colour right out, with never the risk of a throw-back' (Capricornia 289).

Like the vision of absorption's natal-thanatopolitics, both of Herbert's major 'Aboriginal' novels end with the death of an Aboriginal character and, by extension, the figural tragedy of the death of a certain element of Aboriginality. After Norman is acquitted of Frank McLash's murder, he returns to Red Ochre station to rebuild his life. There, in the novel's closing lines, he discovers, in the stocktanks, '[a] human skull - no - two - a small one and a tiny one ... Tocky and her baby!' (448). Where Norman survives to build the new nation on the combination of his sublation of Aboriginality and white 'bastard' genius, his 'half-caste' lover Tocky and their infant die as a tragic result of the inability of the law to police combos like McLash and part-Aboriginal and part-'Asiatics' like Charles Ket. This tragic ending can be read as a specific indictment of the administration of the time; an administration of which Herbert was a vehement critic. However, reading through the lens of biopolitical correspondence, one can also see the death of Tocky as the condition of Norman's sublation. While Tocky is depicted as a failed subject of assimilation and a victim of the Aboriginal compound, Norman's successful assimilation and his reconciliation with his father can be read as the parallel conditions for his survival. In their dialogue, Differ corrects Oscar for his assertion that Norman's whitened racial inheritance is 'submerged' (70). Norman emerges as a white part-Aboriginal with a future in the 'new Nation', whereas Tocky is sacrificed to the thanatopolitics of race. As Monahan argued, it is Norman's whiteness that is emphasised. The tragedy of 'Capricornian' society is that it will not recognise the future potential of the 'Euraustralian'. Norman's Aboriginality is de-emphasised, it is able to 'enrich' with its 'blood' but, as McRandy underlines: 'you'll get the colour right out, with never the risk of a throw-back'. Herbert's sacrifice of Tocky and his further redemption of Norman imply that, in this vision, Aboriginal survival is less significant than the degree to which Aboriginality can 'enrich the new Nation with [its] blood'.

Later in his career, Herbert would depict the loss of a possible hybrid, or creole, Australia as a tragedy. This tragic mode operates in his late work as a past conditional. In 1976's Poor Fellow My Country Jeremy Delacy, the 
white patriarch and grandfather of the part-Aboriginal protagonist Prindy, tells a visiting cattle inspector,

'In my opinion a beautiful breed of people could have been created if only our forefathers'd had the courage to breed with the Aborigines like men, instead of dirty little boys ... and one that would have loved the land because they truly belonged to it ...' Jeremy launched into his subject of what Australia might bave been as a Creole nation. (Poor Fellow 110; emphasis added)

The hybrid potential of a new 'breed of people' is the source of this tragic conditional past nation that might have been, but has failed to come to fruition. Herbert's late work draws inspiration from the tragic failure of racial hybridity that he, in the 1930s, had seen as the potential font of nationhood.

Monahan has emphasised the development of Herbert's politics from the assimilationist Capricornia to Prindy's agency and access to his 'rown road' in Poor Fellow My Country. There remain, however, a number of assimilationist strategies and thanatopolitical imaginaries occluded in this reading. The closing deaths of the latter novel reinscribe and even accentuate a view of hybridity undergirded by the death of Aboriginality - a loss given the tone of a tragedy, but a death nonetheless. At Poor Fellow My Country's close, the two main characters, Delacy and Prindy, are killed when Delacy interrupts Prindy's initiation ceremony. Whereas Prindy's death signals the failure of the part Aboriginal to produce an effective hybrid identity for the new nation, the close of the novel brings about Herbert's desired legitimisation of 'bastard whitefella genius' in Delacy's death. In Prindy's death, Delacy's alienation from true hybrid Australianness is sublated and overcome as he finds himself rooted in the soil, as he has so desired through the novel. He declares with his dying breath, 'to die ... like this ... but ... how better? The debt ... the ... the ancient debt ... paid ... Old Yalmaru ... come ... get me ...' (Poor Fellow 1444). It is as if, as Huggan suggested, the appropriation of Aboriginal culture through assimilation aims to produce an authentic nativism for the white inhabitants of the settler colony. In the face of this nativist appropriation, Aborigines of mixed descent are destined to death, alienation, and to act as the conduit for this 'bastard' desire for rootedness. Prindy's and Jeremy's deaths symbolically guarantee a future hybridity of spirit for the Australian nation, one supplied by the maintenance of traditional Aboriginal custom. Yet, this vision of hybridity sacrifices the young Aboriginal protagonist Prindy in order to transmute his death into the spiritually meaningful death of the white settler. Prindy's death marks the meeting of Delacy with his whitefella Yalmaru (spirit double); in Herbert's imagining, it is Delacy whose spirit transcends these deaths and he finally finds himself at home on the soil of which he is an invader. It is Delacy who benefits from hybridity; Prindy merely dies. Poor Fellow My Country reiterates a spectral trace of the logic of the doomed race by marking the death of the part-Aboriginal child as a means to the end of the cultural appropriation of Aboriginality qua settler rootedness.

Monahan stresses the relative agency displayed by Herbert's Aboriginal characters and sees this as an index of the transformation of Herbert's awareness of race between Capricornia and Poor Fellow My Country. His discussion risks uncritically reifying Herbert's hybrid vision while failing to observe adequately the degree to which it ghosts and repeats an assimilationist vision of miscegenation. Monahan comes closest to this uncritical avowal of Herbert's nationalism when he, for instance, writes 'the half-caste hero Prindy ... offers symbolic hope for an Australia in which new and old can join in productive harmony' (80). According to this reading, Herbert's success as a settler writer depicting Aboriginal people is evaluated by the very logic that reproduces the biopolitical norms discussed in the first part of this essay. Precisely because Aboriginality is appreciated as something to be transvalued for the benefit of settler Australian subjects, Herbert's novels refuse to establish a legitimate place for Aboriginality on its own terms. As I have tried to show, the generic device of tragedy must be connected to the persistent spectre not only of the doomed race theory but also of the thanatopolitical conception that Aboriginality could be bred out of the life of the nation. While, as we have seen, Herbert did not necessarily share Neville's vision of an Australian future wherein Aboriginality would be forgotten, he did subscribe to an assimilationist hybridity reminiscent of Cleland's ideas. By closing with the transvalued spiritual death of Jeremy Delacy, Poor Fellow My Country, even more fully than Capricornia, embeds its exploration of Aboriginal custom in a crypto-assimilationist logic, wherein the primary goal of writing Aboriginality is to emphasise settler hybridity as the basis for cultural independence.

The pervasiveness of the doomed race theory, its transformation into a natal-thanatopolitics, and the disciplinary function of miscegenation and stolen children cast a heavy shadow on otherwise well-intentioned texts by settler writers of the time. The limits of Herbert's empathy lie in the form of hybridity immanent to his project and this reflects the assimilationist programs of his time. It is significant also that Herbert did not successfully emplot this idea of 'bastard whitefella genius' through the appropriation of Aboriginality until his later novel, even though, as we see, he had been developing the notion since the late 1930s. Where Monahan sees Poor 
Fellow My Country as more successful in its depiction of Aboriginality, I would suggest that its return to tragedy with the death of the "half-caste hero' confirms how insistent the thanatopolitical influence was on even Herbert's later writing. As a cultural imaginary, the thanatopolitical trope of the doomed race outlasts assimilation itself, passing into the public sphere via texts like Poor Fellow My Country and Nicholas Roeg's 1971 film Walkabout, which closes with the suicide of David Gulpilil's character (credited only as 'black boy').

Stephensen's vision of a 'new human type' for a future white Australia indicates that his idea of national futurity may well have shared its telos with aspects of the absorptionist worldview: if not that of Aboriginal disappearance, certainly that of the value of hybridity that privileges the cultural identity of the settler. Herbert's view of the Aboriginal place in the nation is more assured: his emphasis on 'combo-ism' and miscegenation orients towards a positive vision of hybridity, while he also stressed, like the Jindyworobaks, the cultural legitimacy of the settler appropriating Aboriginal motifs. Yet, as I have tried to show, these aspects of Herbert's project also risked reiterating the assimilationist and absorptionist logics that we find in the policy frameworks of the time. This correspondence establishes the uncomfortable relationship between Australian literary nationalism and a peculiarly settler biopolitics that continues to inform visions of a (post)colonial Australia in ways that are still to be examined.

\section{WORKS CITED}

Australian Aborigines Conference: Sesquicentenary Day of Mourning and Protest to Be Held in the Australia Hall Sydney. Sydney: Aborigines Progressive Association, 1938. Flyer held at AIATSIS Library.

Agamben, Giorgio. Homo Sacer: Sovereign Power and Bare Life. Trans. Daniel Heller-Roazen. Stanford: Stanford UP, 1998.

- State of Exception. Trans. Kevin Attell. Chicago: U of Chicago P, 2005

Allen, Chadwick. Blood Narrative: Indigenous Identity in American Indian and Maori Literary and Activist Texts. Durham: Duke UP, 2002.

Anderson, Warwick. The Cultivation of Whiteness: Science, Health, and Racial Destiny in Australia. New York: Basic, 2003.

Bashford, Allison. Imperial Hygiene: A Critical History of Colonialism Nationalism, and Public Health. New York: Palgrave, 2004.

Briscoe, Gordan. Counting, Health, and Identity: A History of Aboriginal Health and Demography, 1900-1940. Canberra: Aboriginal Studies P, 2003.
Commonwealth of Australia. Aboriginal Welfare: Initial Conference of Commonwealth and State Aboriginal Autborities Held at Canberra, $21^{\mathrm{st}}$ to 23 ${ }^{\text {rd }}$ April, 1937. Canberra: Government Printer, 1939.

Cusack, Dymphna 'Salute to Jindyworobak.' Jindyworobak Review 1938-48. Melbourne: Jindyworobak, 1948. 42-45.

Dangarembga, Tsitsi. Nervous Conditions. London: Women's Press, 1988.

Dixon, Robert. Prosthetic Gods: Travel, Representation, and Colonial Governance. St Lucia: U of Queensland P, 2001.

Elkin, A.P. Personal Archives. University of Sydney Archives, P. 130.

Esposito, Roberto. Bios: Biopolitics and Philosophy. Trans. Timothy Campbell. Minneapolis: U of Minnesota P, 2008.

Foucault, Michel. Discipline and Punish: The Birth of the Prison. New York: Random House, 1977.

- The History of Sexuality Vol. 1: An Introduction. Trans. Robert Hurley. New York: Pantheon, 1978.

—. "Society Must Be Defended": Lectures at the Collège de France 1975- 6. Ed. Mauro Bertani and Alessandro Fontana. Trans. David Macey. New York: Picador, 2003.

Gray, Geoffrey. A Cautious Silence: The Politics of Australian Antbropology. Canberra: Aboriginal Studies P, 2007.

Griffiths, Michael R. 'Need I Repeat? Settler Colonial Biopolitics and Postcolonial Iterability in Kim Scott's Benang.' Postcolonial Issues in Australian Literature. Ed. Nathanael O'Reilly. Amherst: Cambria, 2010. 157-83.

de Groen, Frances. Xavier Herbert: A Biography. St Lucia: U of Queensland P, 1998.

Haebich, Anna. Broken Circles: Fragmenting Indigenous Families 1800-2000. Fremantle, WA: Fremantle Arts Centre P, 2000.

Huggan, Graham. Australian Literature: Postcolonialism, Transnationalism, Racism. Oxford: Oxford UP, 2007.

Herbert, Xavier. Capricornia. Sydney: Sirius, 1963.

- Poor Fellow My Country. London: William Collins, 1975.

- Letter to A.P. Elkin. 28 November 1936. MS. A.P. Elkin Personal Papers. University of Sydney Archives, Sydney, P. 130, Box 72.

- Letters. Ed. Frances de Groen and Laurie Hergenhan. St Lucia: U of Queensland P, 2002.

Ingamells, Rex. Introduction. Jindyworobak Review 1938-48. Ed. Rex Ingamells et al. Melbourne: Jindyworobak, 1948. 9-29.

— and Ian Tilbrook. Conditional Culture. Adelaide: F.W. Preece, 1938.

Mbembe, Achille. 'Necropolitics.' Trans. Libby Meintjes. Public Culture 15.1 (2003): 11-40.

McGregor, Russell. Imagined Destinies: Aboriginal Australians and the Doomed Race Theory. Carlton: Melbourne UP, 1997. 
Mead, Philip. Networked Language: Culture and History in Australian Poetry. Sydney: Australian Scholarly Publishing, 2008.

Monahan, Sean. A Long and Winding Road: Xavier Herbert's Literary Journey. Crawley, WA: U of Western Australia P, 2003.

Moses, A. Dirk. 'Genocide and Settler Society in Australian History.' Genocide and Settler Society. Ed. A. Dirk Moses. New York: Bergahn, 2004. 3-48.

Munro, Craig. Wild Man of Letters: The Story of P.R. Stephensen. Carlton: Melbourne UP, 1984.

Ngugi wa Thiong'o. Petals of Blood. London: Heinemann, 1977.

Reynolds, Henry. The Other Side of the Frontier: Aboriginal Responses to the European Invasion of Australia. Sydney: U of NSW P, 1981.

Rosaldo, Renato. Culture and Truth: The Remaking of Social Analysis. Boston: Beacon, 1989.

Rowse, Tim. White Flour, White Power: From Rations to Citizenship in Central Australia. Cambridge: Cambridge UP, 1998.

—. 'Notes on the History of the Aboriginal Population of Australia.' Genocide and Settler Society. Ed. A. Dirk Moses. New York: Bergahn, 2004. 31225 .

Rushdie, Salman. Midnight's Children. London: Jonathan Cape, 1981.

Spencer, Walter Baldwin. Preliminary Report on the Aboriginals of the Northern Territory. Melbourne: Government Printer, 1913.

Stephensen, P.R. The Foundations of Culture in Australia: An Essay toward National Self Respect. Gordon, NSW: W.J. Miles, 1936.

—. 'How I edited Capricornia.' Bulletin 15 March 1961: 33-34.

Stoler, Ann Laura. Race and the Education of Desire: Foucault's History of Sexuality and the Colonial Order of Things. Durham NC: Duke UP, 1995.

Strehlow, T.G.H. 'A Message from Mr T.G. Strehlow.' Jindyworobak Review 1938-48. Ed. Rex Ingamells et al. Melbourne: Jindyworobak, 1948. 35.

Taylor, Cuimara Ben. 'A Nyungar is Battling.' Speaking from the Heart: Stories of Life, Family, and Country. Ed. Sally Morgan, Tjalaminu Mia and Blaze Kwaymullina. Fremantle: Fremantle P, 2007. 95-108.

Walkabout. Dir. Nicolas Roeg. Perf. Jenny Agutter, Luc Roeg, and David Gulpilil. Twentieth Century Fox, 1971. Film.

Watts, Rob. 'Making Numbers Count: The Birth of the Census and Racial Government in Victoria 1835-40.' Australian Historical Studies 33.121 (2003): 33-58

Wolfe, Patrick. Settler Colonialism and the Transformation of Anthropology: The Poetics and Politics of an Ethnographic Event. London: Cassell, 1999.

\section{Humanitarian Sex: Biopolitics, Ethics, and Aid Worker Memoir}

\author{
Shameem Black
}

$\mathrm{H}$

umanitarianism is sexy, or so they say. Unlike other forms of civic aid that go by less glamorous names, such as social work, the word 'humanitarian' carries with it a particular glow of grandeur. Because it deploys the language of the human, rather than of the citizen, it is able - indeed compelled - to range promiscuously across national borders in search of bodies to claim as its proper object of attention. This inbuilt distance between the social worlds of the aid worker and of the recipient of aid lends itself to an erotics of the exotic that bespeaks polysemous forms of desire. Humanitarianism is sexy, in the sense that it makes humanitarians seem enticingly chic; it is also sexualised, caught up in a romance narrative of endless longing for a strange other.

With its roots in missionary colonialism (Rieff 59-66), Western humanitarian aid work in the late twentieth and early twenty-first centuries has traditionally taken as its object of desire the suffering body of the nonWestern 'other' to be managed at the hands of the Western aid worker. As these non-Western subjects are physically recalibrated through medical intervention, food aid, peacekeeping operations, resettlement programs, and other forms of biopolitical management, these encounters dramatise the powerful ways in which the administration of bodies in a globalising era is often the legacy of imperialism and its erotics of international encounter. In this essay, I seek to put pressure on the trope of sexy humanitarianism to consider how actual sex in the context of international aid helps us understand the cultural logic of contemporary humanitarian work. How does the trope of sex help us think through the biopolitics and ethics of global encounters in situations of extreme inequality and violence? 